\title{
PERJANJIAN PERKAWINAN PERAMPAM DENE DALAM ADAT GAYO DITINJAU DARI KITAB UNDANG-UNDANG HUKUM PERDATA DAN HUKUM ISLAM ${ }^{1}$
}

\author{
Suhartini, Syandi Rama Sabekti \\ Sekolah Tinggi Ilmu Hukum Muhammadiyah Aceh Tengah \\ Jl. Qurata Aini, Gunung Bukit Mampak Kebayakan, Takengon, Kab. Aceh Tengah \\ suhartini.gayo@gmail.com
}

\begin{abstract}
In gayo adat law known as a marriage agreement with the term perampam dene, which is a fine given to a husband or wife who violates a covenant in the marriage, this agreement perampam dene is made by mutual agreement between the husband and wife witnessed by the person parents both husband and wife or family and known by reje (village head) both sides. The type of research used in this study is empirical juridical research is legal research at first is the library data which is then followed by field research. Implementation of the Marriage Agreement of Dene in the Gayo society is done in front of the sarak opat, where the parties read the dene taker agreement in front of the sarak opat witnessed by the family, the contents of the denfilling agreement contains the customary sanction if one of the couple violates will be given sanction as written in the tamper dene agreed upon by both parties. The position of the marriage agreement dene when viewed from Islamic law the position of the law is very strong because dene based on recitation of Al-Qur'an and hadits, if viewed from the Civil Code the position of marriage agreement perampam dene not strong.
\end{abstract}

Keywords : Perampam Dene; Gayo Tradition; Islamic Law and Civil Code

\begin{abstract}
Abstrak
Dalam hukum adat Gayo dikenal suatu perjanjian perkawinan dengan istilah perampam dene, yaitu suatu denda yang diberikan kepada seseorang pasangan suami atau isteri yang melanggar sebuah perjanjian di dalam perkawinan, perjanjian perampam dene ini dibuat oleh kesepakatan kedua belah pihak antara suami dan isteri yang disaksikan oleh orang tua kedua pasangan suami isteri atau keluarga dan diketahui oleh reje (kepala desa) kedua belah pihak. Jenis penelitian yang digunakan dalam penelitian ini adalah penelitian yuridis empiris atau penelitian hukum sosiologis. Penelitian hukum empiris, yang deteliti pada awalnya adalah data sekunder yang kemudian dilanjutkan dengan penelitian pada data primer di lapangan. Pelaksaan perjanjian perkawinan perampam dene, para pihak yang yang datang kepada Reje sendiri tanpa ada paksaan, setelah sarak opat menemukan titik temu dalam permasalahan yang dihadapi oleh para pihak, para pihak membacakan isi dari perjanjian perkawinan perampam dene dihadapan unsurunsur sarak opat dan saksi-saksi. Kedudukan Perjanjian perkawinan perampam dene bila ditinjau dari hukum Islam kedudukannya hukumnya sangat kuat karena perampam dene berdasarkan AlQur'an dan hadist, jika ditinjau dari Kitab Undang-Undang Hukum Perdata kedudukan perjanjian perkawinan perampam dene tidak kuat.
\end{abstract}

Kata kunci : Perampam Dene; Hukum Adat Gayo; Hukum Islam Dan KUHPerdata

\footnotetext{
${ }^{1}$ Hibah Penelitian Dosen Pemula (PDP) Direktorat Riset dan Pegabdian Masyarakat (DRPM) Kementerian Riset Dan Teknologi Tahun 2017
} 


\section{A. Pendahuluan}

Undang-Undang Nomor 1 Tahun 1974 Tentang Perkawinan mendefinisikan bahwa perkawinan ialah ikatan lahir bathin antara seorang pria dengan seorang wanita sebagai suami istri dengan tujuan membentuk keluarga yang bahagia kekal dan sejahtera berdasarkan Ketuhanan Yang Maha Esa. Arti perkawinan tersebut dimaksud adalah ikatan lahir batin antara seorang pria dan seorang wanita sebagai suami istri, sedangkan tujuan perkawinan dimaksud adalah membentuk keluarga yang bahagia dan kekal berdasarkan Ketuhanan Yang Maha Esa.

Perkawinan bukan saja berarti sebagai perikatan Perdata, tetapi juga merupakan perikatan adat dan sekaligus perikatan kekerabatan dan ketetanggaan. Dengan kata lain, terjadinya suatu ikatan perkawinan bukan semata-mata membawa akibat terhadap hubungan ke perdataan, seperti hak dan kewajiban suami isteri, harta bersama, kedudukan anak, hak dan kewajiban orang tua, tetapi juga menyangkut hubungan adatistiadat, kewarisan, kekeluargaan, kekerabatan, ketetanggaan serta menyangkut upacaraupacara adat dan keagamaan (Hadikusuma, 2007).

Perkawinan banyak hal yang dapat menyebabkan timbulnya permasalahan, seperti masalah hak dan kewajiban sebagai suami isteri, masalah keuangan rumah tangga, masalah prinsip, dan berbagai hal lainnya. Selain masalah-masalah tersebut di atas, maka masalah harta benda juga merupakan salah satu faktor penyebab yang sering terjadi yang dapat menyebabkan timbulnya berbagai perselisihan atau pertengkaran dalam suatu perkawinan, bahkan dapat mengakibatkan terjadinya perceraian antara suami isteri.

Perkembangan yang terjadi di masyarakat sekarang ini banyak terjadinya permasalahan yang dihadapi oleh suami isteri dalam menjalankan kehidupan perkawinan mereka terutama dalam hal harta kekayaan yang diperoleh masing-masing pihak selama dalam perkawinan, sehingga perjanjian perkawinan menjadi sebuah solusi untuk melindungi harta kekayaan masing-masing pihak (Mulyadi, 2008).
Perjanjian kawin adalah perjanjian atau persetujuan yang dibuat oleh calon pasangan suami isteri sebelum atau pada saat perkawinan dilangsungkan untuk mengatur akibat-akibat perkawinan terhadap harta kekayaan mereka (Prawirohamidjojo, 2002).

Secara umum, perjanjian perkawinan berisi tentang pengaturan harta kekayaan calon suami istri. "Tujuan dari pembuatan perjanjian perkawinan adalah untuk mengatur akibatakibat perkawinan yang menyangkut karta kekayaan” (Susanto, 2008). Perjanjian perkawinan ini bersumber pada Kitab UndangUndang Hukum Perdata yang diatur dalam buku I Bab ke VII dari Pasal 139 sampai Pasal 154, dan Pasal 29 Undang-Undang Nomor 1 Tahun 1974 tentang Perkawinan yang menyebutkan :

1. Pada waktu atau sebelum perkawinan dilangsungkan, kedua pihak atas persetujuan bersama dapat mengadakan perjanjian tertulis yang disahkan oleh Pegawai Pencatat Perkawinan, setelah mana isinya berlaku juga terhadap pihak ketiga sepanjang pihak ketiga tersangkut.

2. Perjanjian tersebut tidak dapat disahkan bilamana melanggar batas-batas hukum, agama dan kesusilaan.

3. Perjanjian tersebut mulai berlaku sejak perkawinan dilangsungkan.

4. Selama perkawinan berlangsung perjanjian tersebut tidak dapat dirubah, kecuali bila dari kedua belah pihak ada persetujuan untuk merubah dan perubahan tidak merugikan pihak ketiga.

Bentuk dan isi perjanjian perkawinan pada umumnya, kepada kedua belah pihak diberikan kebebasan asalkan tidak bertentangan dengan batas-batas hukum, agama, dan kesusilaan. Perjanjian perkawinan dibuat sebelum atau pada saat perkawinan dilangsungkan, dan harus dibuat dengan akta Notaris sebagaimana ditegaskan dalam Pasal 147 juncto Pasal 149 Kitab Undang-Undang Hukum Perdata, yaitu : perjanjian perkawinan itu harus dibuat dengan akta Notaris sebelum dilangsungkannya perkawinan, perjanjian mulai berlaku semenjak saat perkawinan dilangsungkan dan tidak boleh ditarik kembali atau diubah dengan 
cara bagaimanapun selama berlangsungnya perkawinan.

Pada dasarnya pelaksanaan perkawinan yang dilakukan oleh masyarakat Gayo sama halnya dengan perkawinan adat masyarakat Indonesia terutama yang menganut agama Islam. Suku Gayo merupakan bagian dari wilayah kekuasaan Sultan Iskandar Muda dari kesultanan Aceh, suku Gayo adalah suku minoritas yang berbeda kebudayaanya dengan budaya suku Aceh. Dalam hukum adat gayo dikenal suatu perjanjian perkawinan dengan istilah perampam dene, yaitu suatu denda yang diberikan kepada seseorang pasangan suami atau isteri yang melanggar sebuah perjanjian di dalam perkawinan, perjanjian perampam dene ini dibuat oleh kesepakatan kedua belah pihak antara suami dan isteri yang disaksikan oleh orang tua kedua pasangan suami isteri atau keluarga dan diketahui oleh reje (kepala desa) kedua belah pihak.

Penelitian ini tentang "Perjanjian Perkawinan Perampam Dene Dalam Adat Gayo Ditinjau Dari Kitab Undang-Undang Hukum Perdata Dan Hukum Islam" belum pernah dilakukan oleh peneliti lain. Berdasarkan uraian di atas, maka permasalahan yang diangkat dalam penelitian ini, Pertama, bagaimana pelaksanaan perjanjian perkawinan perampam dene dalam Hukum Adat Gayo di Kabupaten Bener Meriah. Kedua, Bagaimanakah kedudukan hukum perjanjian perkawinan perampam dene ditinjau dari Kitab Undang-Undang Hukum Perdata dan Hukum Islam?

\section{B. Metode Penelitian}

Jenis penelitian yang digunakan dalam penelitian ini adalah penelitian yuridis empiris yaitu penelitian hukum pada awalnya adalah data pustaka yang kemudian dilanjutkan dengan penelitian lapangan.

Sumber data dalam penelitian ini data primer yaitu data yang diperoleh dilapangan yang diperoleh melalui wawancara secara langsung dengan informan dan responden yang berkaitan dalam penelitian ini. Sedangkan data sekunder bersumber dari bahan pustaka berupa bahan hukum primer yang diperoleh dari peraturan perundang- undangan yang meliputi : Undang-Undang Dasar 1945, Kitab Undang-Undang Hukum Perdata (KUH Perdata), Undang-Undang Nomor 1 Tahun 1974 tentang Perkawinan, Instruksi Presiden Nomor 1 Tahun 1991 tentang Kompilasi Hukum Islam, bahan hukum sekunder adalah bahan hukum yang sifatnya menjelaskan bahan hukum primer, yaitu berupa buku, karya ilmiah, sedangkan bahan hukum tersier adalah bahan hukum yang dijadikan sebagai pelengkap bahan hukum primer dan bahan hukum sekunder yang berupa Kamus Hukum ataupun Kamus Besar Bahasa Indonesia.

Teknik pengumpulan data dilakukan dengan wawancara dan studi dokumen untuk mendapatkan data dan informasi secara langsung tentang permasalahan dalam penelitian ini. Data yang diperoleh dianalisis secara deskriptif kualitatif, yaitu menganalisis, mengelompokkan dan menyeleksi data yang diperoleh dari penelitian lapangan kemudian dihubungkan dengan teori-teori atau penelitian pustaka.

\section{Hasil dan Pembahasan \\ 1. Pelaksanaan Perjanjian Perkawinan Perampam Dene}

Perkawinan merupakan kesepakatan bersama antara suami dan istri untuk melakukan hidup bersama, dan tentu saja mengakibatkan hak dan kewajiban bagi kedua belah pihak. Suami isteri yang terikat dalam perkawinan sah, akan mempunyai harta benda baik yang diperoleh sebelum perkawinan maupun selama perkawinan. Hal inilah yang biasanya banyak menjadi dasar timbulnya permasalahan di kemudian hari dalam kehidupan rumah tangga suami istri, sehingga dibuatnya perjanjian perkawinan akan menjadi salah satu solusi untuk mencegah timbulnya permasalahan mengenai harta benda kekayaan tersebut. Calon suami isteri sebelum melakukan perkawinan dapat membuat perjanjian perkawinan di mana perjanjian perkawinan sebenarnya merupakan persetujuan antara calon suami istri untuk mengatur akibat hukum perkawinan terhadap harta kekayaan mereka.

Perkawinan dalam adat Gayo mempunyai arti yang sangat penting terhadap sistem 
kekerabatan karena masyarakat Gayo menganut sistem Perkawinan exogami (perkawinan antar belah atau antar klan). Menurut adat masyarakat Gayo perkawinan dengan sistem endogami (kawin satu belah atau satu klan) menjadi larangan atau pantangan karena sesama klan masih dianggap masih memiliki ikatan persaudaraan atau ikatan darah. Dengan demikian akan memudahkan hubungan genealogis antara satu kampung dengan kampung lainnya.

Ada 3 (tiga) macam jenis perkawinan yang terdapat dalam masyarakat Gayo yaitu Kawin ango atau jeulen, kawin angkap dan kawin kuso kini, yaitu : (Coubat, 1984).

a. Kawin ango atau juelen adalah satu corak perkawinan asii menurut adat di dalam masyarakat suku-bangsa Gayo. Perkawinan juelen sering juga disebut dengan kerje berunyuk, Disebut demikian karena orang tua si calon istri menerima apa yang disebut dengan istilah unyuk sehingga akibat unyuk ini si calon istri kelak menurut adat masuk ke dalam belah suaminya, begitu pula dengan anak-anak yang dilahirkan. Maksud sebenarnya perkawinan juelen ini adalah bertujuan untuk mencegah supaya tidak terjadi perkawinan dengan seseorang yang masih mempunyai hubungan darah terlalu dekat. Dua orang bersaudara perempuan atau lebih, yang kawin dengan status juelen dengan laki-laki dari belah-belah lain, maka istri-istri mereka ini disebut sara ralik, sedangkan anak-anak yang lahir akibat perkawinan itu dinamakan sara anak juelen. Status kawin juelen ini sangat berat bagi calon suami karena harus memenuhi tuntutan syarat-syarat tertentu yang cukup berat yang dinamakan edet.

b. Kawin Angkap, ini lebih kurang dapat disamakan dengan japuik (jemputan) di Minangkabau. Munculnya status angkap ini di Gayo karena faktor tuntutan keadaan. Umpamanya saja, sepasang suami istri yang tidak mempunyai anak laki-laki. Untuk mendapatkan seorang anak laki-laki, suami istri ini mencari seseorang sebagai teman hidup anak perempuannya dengan jalan perkawinan angkap itu. Berhubung karena laki-laki yang menjadi menantunya dari belah lain, sedangkan status perkawinannya adalah angkap, maka laki-laki ini meninggalkan belahnya dan masuk ke belah istrinya beserta anak-anak yang dilahirkan. Si suami dari perkawinan itu akan memakai marga istrinya. Dari uraian di atas dapat disimpulkan bahwa status perkawinan angkap itu, tidak lain mengambil seorang laki-laki (bujang atau pernah menduda) dengan jalan perkawinan dan ia disahkan sebagai anak kandung sebelum ada perceraian.

c. Kawin kuso kini adalah suatu bentuk perkawinan yang memberi kebebasan kepada suami istri untuk memilih tempat tinggal dalam belah suami atau belah istri. Pada kawin kuso kini, suami istri dapat menetap pada keluarga atau mandiri pada rumah dan pekerjaan mereka sendiri tetapi tetap memandang dan membantu keluarga kedua belah pihak dengan baik. Bentuk perkawinan kuso kini ini berbeda dengan perkawinan anggo dan angkap yang selalu mempertahankan belah. Bentuk perkawinan ini masih banyak pula terjadi dalam masyarakat Gayo hingga sekarang. Upacara daur hidup (life cycle) merupakan kegiatan sedere dalam bentuk pakat sedere dengan tujuan agar dapat dicapai suatu kesepakatan dalam melaksanakan setiap kegiatan bersama. Mengenai bentuk-bentuk upacara daur hidup tersebut dapat berwujud pada upacara turun mandi bayi (cukur rambut), bereles (sunat rasul). Bagi anak laki-laki yang berumur 10 tahun ke atas, upacara perkawinan dan kemudian setelah adanya kematian. Semua kegiatan upacara tersebut merupakan kegiatan sedere.

Adat Gayo merupakan penunjang pelaksanaan hukum Islam, karena ukum mu nukum bersifet kalam, edet mu nukum bersifet wujud yang artinya adalah hukum Islam menetapkan hukum berdasarkan firman Allah dan Sunnah Rasulullah, sedangkan adat menetapkan hukum berdasarkan kenyataan yang terjadi yang harus dilakukan untuk 
penunjang pelaksanaan syariat. (Ibrahim dan Aman Pinan, 2010)

Di Indonesia, terdapat 3 (tiga) peraturan yang mengatur masalah perjanjian perkawinan, yaitu Kitab Undang-Undang Hukum Perdata, Undang-Undang Nomor 1 Tahun 1974 tentang Perkawinan, dan Kompilasi Hukum Islam. Perjanjian perkawinan bertujuan untuk melindungi kedudukan harta benda setelah perkawinan, sehingga tidak akan berbuat sewenang-wenang terhadap harta benda yang telah diperjanjikan. Apa yang diperjanjikan berlaku sebagai undang-undang yang mengikat masing-masing pihak yang melakukan perjanjian sehingga apabila perjanjian tersebut dilanggar maka dapat diajukan gugatan pembatalan perkawinan dan gugatan ganti rugi ke Pengadilan, juga bisa dijadikan sebagai alasan perceraian.

Perjanjian perkawinan Perampam Dene dalam masyarakat Gayo lahir dari kebiasaan, yaitu suatu perbuatan yang dilakukan secara berulang-ulang oleh masyarakat, dipatuhi sebagai nilai-nilai hidup yang positif, pola kebiasaan itu diterima sebagai sesuatu yang mengikat dan ditaati oleh masyarakat. Di masyarakat Gayo, Perampam dene, dari asal katanya Perampam yang artinya jatuh atau runtuh, dan Dene yang artinya denda terhadap pasangan yang melanggar perjanjian perkawinan, dan mempunyai akibat hukum pasakh. Jadi Perampam dene adalah suatu denda yang diberikan kepada seseorang pasangan suami atau isteri yang melanggar sebuah perjanjian di dalam perkawinan. Perjanjian perkawinan atau perampam dene ini, dibuat dengan maksud agar ikatan perkawinan kedua belah pihak tetap kuat dan utuh.

Di dalam hukum positif tujuan perjanjian perkawinan untuk mengatur akibat perkawinannya terhadap harta kekayaan mereka. Inti perjanjian perkawinan adalah kesepakatan antara calon suami isteri yang akan menikah untuk memisahkan kepemilikan harta dan utang piutang, dan kesepakatan tentang sejumlah hal penting lain pada saat mengarungi bahtera rumah tangga. Perjanjian perkawinan biasanya dilakukan sebelum atau pada saat berlangsungnya perkawinan sebagaimana yang diatur dalam Kitab UndangUndang Hukum Perdata dan Undang-Undang Perkawinan.

Perjanjian perkawinan Perampam dene dalam masyarakat Gayo bukanlah semata-mata memperjanjikan harta benda yang dimiliki, tetapi lebih kepada perjanjian untuk hidup bersama dalam hal saling mencintai dan tolong menolong dalam membina rumah tangga yang rukun dan bahagia, yang paling penting adalah kesetiaan masing-masing pasangan suami isteri.

Perampam dene berfungsi sebagai pedoman bagi pasangan suami istri agar tidak melakukan perbuatan yang tidak sesuai dengan adat dan agama, dan bertujuan untuk mempersulit perceraian, karena di dalam perampam dene memuat aturan-aturan yang harus ditaati beserta sanksi adat bagi pasangan yang melanggar perampam dene.

Pelaksanaan perampam dene dilakukan dihadapan sarak opat, Adapun peran sarak opat dalam masyarakat Gayo sebagai hakim adat dalam setiap penyelesaian sengketa di tingkat kampung. Sarak opat terdiri dari 4 (empat) macam unsur yang saling berbeda antara satu dengan yang lainnya, dan masingmasing memiliki karakteristik tersendiri, yaitu antara lain; Reje Musuket Sipet (Raja harus berusaha menegakkan keadilan, kebenaran dan kasih sayang diantara anggota belahnya), Imem Muperlu Sunet (Imam/ulama harus senantiasa mengajarkan nilai-nilai agama Islam kepada anggota belahnya), Petue Musidik Sasat (Cerdik pandai/kaum terpelajar harus senantiasa mengamati, menyelidiki, bahkan mengetahui semua keadaan dan perkembangan dalam belahnya), dan Rakyat Genap Mupakat (rakyat melaksanakan berbagai tugas yang dibebankan kepada masing-masing anggota).

Tahap pelaksanaan perjanjian perkawinan perampam dene, yaitu :

1) Para pihak yang datang kepada Reje kampung sendiri tanpa ada paksaan;

2) Para pihak berinisiatif datang kepada Reje kampung dan hendak "meminta pendapat kepada Reje kampung perihal perjanjian perkawinan perampam dene untuk 
menyelesaikan masalah rumah tangga yang sedang dihadapi oleh para pihak".

3) Reje Kampung mengumpulkan unsurunsur sarak opat untuk mencari titik temu dalam permasalahan tersebut, setelah tercapai kesepakatan perjanjian perkawinan perampam dene itu dibacakan dan para pihak mendatatangani isi perjanjian tersebut dihadapan sarak opat.

Isi perjanjian perkawinan perampam dene, yaitu :

a) Memuat indentitas pasangan suami isteri Indentitas yang tercantum dalam perjanjian perkawinan perampam dene yang berisi :

(1) Nama

(2) Tempat Tanggal Lahir

(3) Agama

(4) Pekerjaan

(5) Alamat

b) Pernyataan kedua belah pihak pernyataan ini juga dapat diuraikan dengan kalimat sebagai berikut : "Bahwa saya (pihak lakilaki) telah mengambil (nama istri) menjadi istri saya yang sah dalam ikatan perkawinan, saling mengasihi, mencintai dan menghormati sebagaimana layaknya kehidupan berumah tangga baik dalam keadaan suka maupun duka." Selanjutnya pernyataan dari pihak perempuan, bahwa "Saya (nama mempelai perempuan) berjanji juga seperti suami saya sudah berjanji seperti dalam pasal tersebut di atas."

c) Sanksi apabila salah satu pihak mengikari perampam dene, sanksi ini dinyatakan menggunakan kalimat sebagi berikut : "Apabila salah satu diantara kami dari pihak pertama ataupun pihak kedua mengingkari surat perjanjian ini sehingga mengakibatkan perceraian, maka pihak yang bersalah dihukum dan wajib membayar denda pelanggaran adat sebesar (besaran uang yang telah disepakati kedua belah pihak) secara kontan (tunai).

d) Cara penyelesaian masalah, penyelesaian masalah sebagai antisipasi apabila terjadi sengketa dan permasalahan di kemudian hari merupakan suatu substansi yang terdapat dalam perjanjian perkawinan perampam dene ini, hal ini dituangkan sebagai berikut : "Apabila dikemudian hari terjadi permasalahan dalam rumah tangga kami, dan kami tidak mampu menyelesaikan sendiri, kami bersepakat diselesaikan melalui jalur kekeluargaan dan apabila masih belum dapat penyelesaian maka kami sepakat menyerahkan penyelesaian permasalahan melalui Sarak Opat"

Alasan pasangan suami isteri melakukan perjanjian perkawinan perampam dene, yaitu, perampam dene telah menjadi adat istiadat, sehingga perlu untuk terus melestarikannya karena orang Gayo menganggap perkawinan itu sebagai sesuatu yang luhur dan suci biasanya menginginkan agar perkawinan berlangsung seumur hidup bagi suami-istri dan hanya maut yang boleh memutuskan ikatan tersebut.

Isnaini menambahkan, Perjanjian perkawinan perampam dene dapat mencegah perceraian, karena bagi pasangan suami isteri yang membuat perampam dene akan selalu ingat dengan perjanjian yang mereka buat dan akan menjadi patokan hidup dalam berumah tangga.

Menurut Ridwansyah, perampam dene memiliki sanksi bagi pihak yang melanggar perjanjian perkawinan perampam dene, sanksinya berupa denda baik uang ataupun emas, sehingga pasangan suami isteri yang membuat perjanjian perkawinan perampam dene akan berpikir berulang kali untuk melanggar perjanjian perkawinan perampam dene dan menyebabkan mereka berkewajiban untuk membayar denda tersebut.

Berdasarkan uraian diatas, Perjanjian perkawinan perampam dene yang masih berlaku dalam masyarakat Gayo, tidak bertentangan dengan batasan perjanjian perkawinan yang diatur Peraturan PerundangUndangan dan Hukum Islam, menyebutkan bahwa perjanjian perkawinan tidak boleh bertentangan dengan batas-batas hukum, agama dan kesusilaan, apabila bertentangan dengan hal tersebut maka perjanjiannya tidak sah. Namun yang menjadi kajian penulis yakni mengenai adanya denda dalam perjanjian perkawinan perampam dene, yang terasa 
masih tabu di dalam hukum nasional Indonesia. Dalam pengaturan mengenai perjanjian perkawinan hanya dijelaskan bahwa perjanjian perkawinan diutamakan untuk mengatur mengenai pemisahan harta benda saja, tidak termasuk didalamnya adanya hukuman terhadap pelanggaran perjanjian. Namun melihat perjanjian perkawinan perampam dene yang masih berlaku dalam masyarakat Gayo, merupakan hal yang sangat wajar dalam sebuah perjanjian adanya klausul mengenai sanksi atas pelanggaran. Dalam hal ini denda cerai yang diterapkan dalam perjanjian perkawinan sebagaimana pengaturan mengenai adanya wanprestasi dalam sebuah perjanjian. Ketika salah satu pihak gagal memenuhi kewajibannya (prestasinya) maka akan dikenakan sanksi sesuai dengan kesepakatan pada awal pembuatan perjanjian.

\section{Kedudukan Hukum Perjanjian Perkawinan Perampam Dene Ditinjau dari Kitab Undang-Undang Hukum Perdata dan Hukum Islam}

Hubungan antara hukum adat Gayo dan hukum Islam ini adalah hubungan yang sangat erat, sebagaimana dalam istilah adat Gayo "Hukum Ikanung Edet, Edet Ikanung Agama". Artinya setiap hukum mengandung adat, dan setiap adat mengandung agama. Hukum adat adalah anak kandung dari hukum agama. Dengan perkataan lain, hukum adat di dalam pemerintahan Gayo pada hakikatnya adalah merupakan "pancaran dari hukum Islam." Selain itu hubungan hukum adat Gayo dan hukum Islam dapat dihayati dari ungkapan adat seperti (Agama urum edet, lagu zet urum sifet, agama kin senuwen, edet ken peger) artinya Agama Islam dan adat Gayo seperti zat dan sifat, agama sebagai tanaman, adat sebagai pagarnya. Dari ungkapan tersebut jelas dan tegas, bahwa keterpaduan di antara adat dan syaria`at Islam sangat erat dan saling menunjang. Hal ini menjelaskan perampam dene yang masih berkembang di dalam masyarakat gayo bersumberkan dari hukum Islam.

Dalam hukum Islam, perjanjian perkawinan lebih dikenal dengan taklik talak.
Taklik talak merupakan suatu pernyataan kehandak sepihak dari sang suami yang segera diucapkan setelah akad nikah itu berlangsung dan tertera dalam akta nikah. Taklik talak ini dilakukan untuk memperbaiki dan melindungi hak-hak seorang wanita yang dijunjung tinggi oleh kedatangan Islam, akan tetapi sangat disayangkan kebanyakan isteri tidak mau memperhatikan taklik talak itu ketika diucapkan oleh sang suami. Oleh karena ta'lik talak hanya terdapat dalam perkawinan hukum Islam dan dilakukan setelah upacara akad nikah, ta'lik yaitu perjanjian yang tiap-tiap pihak terikat kepada perjanjian ta'lik. Dalam Hukum Islam perjanjian perkawinan baru sah apabila diperbuat sesudah Ijab Qabul dilangsungkan sebab itulah ta'lik talak yang termasuk dalam perjanjian perkawinan dan dilaksanakan sesudah perkawinan dilangsungkan. Mengenai bentuk perjanjian perkawinan dalam Kompilasi Hukum Islam tidak ada disebutkan secara tegas apakah dilaksanakan secara lisan atau secara tertulis.

Perjanjian perkawinan perampam dene bila ditinjau dari hukum Islam kedudukannya hukumnya sangat kuat karena perampam dene berdasarkan Al-Qur'an dan hadist. Hal ini berkaitan dengan firman Allah SWT dalam surat An-Nisa ayat 128, yaitu :

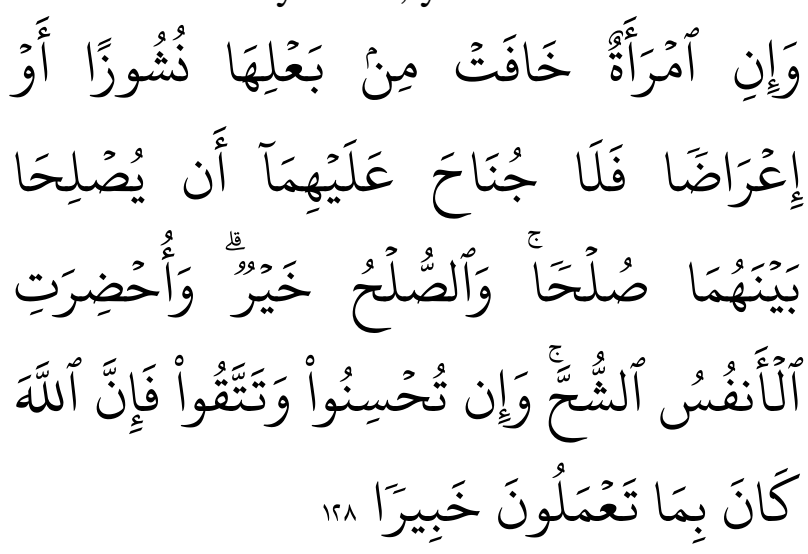

Artinya :

Jika seorang perempuan melihat kesalahan suaminya atau telah berpaling hatinya, maka tiada berdosa keduanya mengadakan perdamaian antara keduanya, berdamai itulah terlebih baik (dari pada bercerai), (memang) manusia itu berpengarai amat kikir, jika kamu berbuat baik (kepada istrimu). Dan bertakwa 
sungguh Allah maha mengetahui apa yang kamu kerjakan(QS. An-Nisa :128).

Perjanjian perkawinan juga diatur dalam AI-Qur'an surat AI-Maidah ayat (1) yang berbunyi :
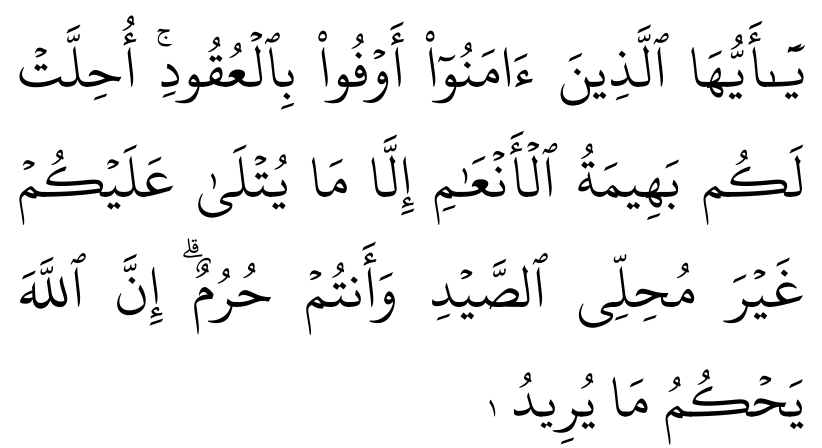

Artinya :

Hai orang-orang yang beriman, penuhilah perjanjian yang kamu perbuat". Ini berarti segala janji yang telah diperbuat dan telah diikat antara sesama manusia demi kepentingan pergaulan mesti dipenuhi. Dengan adanya perjanjian antara sesama manusia ini berarti tidak terlepas terhadap perjanjian antara suami dan isteri, dan perjanjian itu adalah sah.

Pasal 147 Kitab undang-Undang Hukum Perdata, menyebutkan bahwa perjanjian perkawinan harus dibuat secara tertulis, dibuat sebelum perkawinan berlangsung dan mulai berlaku sejak perkawinan dilangsungkan atau dapat juga dilakukan saat perkawinan berjalan ketika ada permasalahan. Perjanjian itu dilekatkan pada akta nikah dan merupakan bagian yang tidak terpisahkan dari surat nikah, dan dibuat atas persetujuan atau kehendak bersama calon pengantin, dibuat secara tertulis, disahkan oleh pegawai catatan sipil, serta tidak boleh bertentangan dengan hukum, agama dan kesusilaan.

Sebelum masyarakat Gayo mengenal huruf (baca tulis), perampam dene hanya dilakukan secara lisan saja di hadapan Sarak Opat dan didepan para saksi yang hadir, ternyata sekarang janji itu sudah sering dilanggar. Perceraian yang dulunya dianggap sebagai sesuatu yang tabu, kini sudah dianggap biasa. Sehingga sekarang "perampam dene dibuat secara tertulis dalam surat perjanjian".

Dalam pembuatan perjanjian kawin harus memenuhi Pasal 147 Kitab Undang-Undang Hukum Perdata yang menentukan perjanjian kawin harus diadakan sebelum perkawinan dalam bentuk akta notaris, apabila tidak maka perjanjian kawin tersebut batal. Selanjutnya dalam Pasal 149 Kitab Undang-Undang Hukum Perdata ditentukan bahwa setelah kawin, janji-janji tersebut tidak boleh diubah. Selain itu Pasal 147 ayat (2) Kitab UndangUndang Hukum Perdata juga mengatur berlakunya perjanjian kawin, yitu "perjanjian kawin mulai berlaku pada saat perkawinan dilakukan, tidak boleh pada saat lain. Jelas disini perjanjian kawin tidak dapat berlaku sebelum perkawinan dilangsungkan”.

Perjanjian perkawinan perampam dene hanya dibuat dihadapan Sarak Opat dan ditandatangani oleh kedua calon mempelai, orang tua, saksi-saksi dari kedua belah pihak, oleh karena itu perjanjian perkawinan perampam dene secara formil tidak mempunyai kekuatan hukum. Pendapat yang sama juga disampaikan Abdul Rahman, jika ditinjau dari Kitab Undang-Undang Hukum Perdata kedudukan perjanjian perkawinan perampam dene tidak kuat, karena perjanjian perkawinan perampam dene bila salah satu pihak melanggar perjanjian tersebut tidak bisa di selesaikan melalui mahkamah syariah, hanya dapat diselesaikan oleh sarak opat.

Kedudukan hukum perjanjian perkawinan perampam dene ditinjau dari hukum Islam memiliki kedudukan hukum yang kuat, karena perjanjian perkawinan perampam dene bersumber dari Al-Qur'an da hadist, namun perjanjian perkawinan perampam dene tidak memiliki kekuatan hukum formil, karena hanya disahkan dihadapan reje kampung tanpa mendaftarkannya kepada pegawai pencatatan nikah. perjanjian kawin harus di buat di hadapaan notaris sehingga mempunyai kekuatan hukum dalam pembuktiannya. Apabila akta perjanjian kawin dibuat di bawah tangan maka akta tersebut tidak memiliki kekuatan hukum dalam pembuktiannya. 


\section{Simpulan}

Berdasarkan hasil penelitian dan pembahasan bahhwa pelaksanaan Perjanjian perkawinan Perampam Dene dalam masyarakat Gayo dilakukan dihadapan sarak opat, dimana para pihak membacakan perjanjian perampam dene di hadapan sarak opat yang disaksikan oleh para keluarga, isi perjanjian perampam dene memuat sanksi adat jika salah satu pasangan melanggar akan diberikan sanksi sebagaimana yang tertulis didalam perampam dene yang telah disepakati kedua belah pihak. Kedudukan Perjanjian perkawinan perampam dene bila ditinjau dari hukum Islam kedudukan hukumnya sangat kuat karena perampam dene berdasarkan AlQur'an dan hadist, jika ditinjau dari Kitab Undang-Undang Hukum Perdata kedudukan perjanjian perkawinan perampam dene tidak kuat.

\section{DAFTAR PUSTAKA}

\section{Buku}

Coubat, Sy, A. (1984), Adat Perkawinan Gayo Kerje Beraturen. Jakarta : Balai Pustaka.

Supramono, G. (1998), Segi-Segi Hukum Hubungan Luar Nikah, Jakarta : Djambatan.

Susanto, H. (2008). Pembagian Harta GonoGini Saat Terjadi Perceraiaan, Jakarta : Visimedia.

Hadikusuma, H. (2007). Hukum Perkawinan Indonesia Menurut Perundangan, Hukum Adat, Hukum Agama, Bandung : Mandar Maju.

Mulyadi. (2008), Hukum Perkawinan Indonesia, Semarang : Badan Penerbit Universitas Diponegoro.

Ibrahim, Mahmud., \& Aman, AR. Hakim. (2010), Syariat Dan Adat Istiadat, Jilid II. Takengon : Maqamammahmuda.

Prodjohamidjodjo, M. (2011). Hukum Perkawinan Indonesia, Indonesia Jakarta : Central Publishing.

Prawirohamidjojo, R. Soetojo., \& Safioedin, Asis. (1987). Hukum Orang dan Keluarga, Cetakan V. Bandung: Alumni.

Prawirohamidjojo, R. Soetojo. (2002). Pluralisme Dalam Perundang-Undangan
Perkawinan Indonesia, Surabaya : Airlangga University Press.

Subekti, R. (1995), Pokok-Pokok Hukum Perdata, Jakarta : Intermasa.

\section{Peraturan Perundang-Undangan}

Kompilasi Hukum Islam

Kitab Undang-Undang Hukum Perdata

Undang-Undang Nomor 1 Tahun 1974 tentang Perkawinan 